\title{
Analisis Pengaruh Profitabilitas, Kebijakan Dividen, Inflasi dan Nilai Tukar terhadap Nilai Perusahaan
}

\author{
Analysis of the influence of profitability, dividend policy, inflation and exchange rate on \\ firm value
}

\author{
Annisa Pujiati \\ Program Studi D4 Keuangan Syariah, Politeknik Negeri Bandung \\ Email: annisa.pujiati.ksy16@polban.ac.id
}

\section{Fatmi Hadiani}

Jurusan Akuntansi, Politeknik Negeri Bandung

Email: fatmihadiani10@gmail.com

\begin{abstract}
The purpose of this research is to determine the effect of profitability, dividend policy, inflation, and exchange rates on firm value. The population of this study is the property, real estate, and building construction sector companies listed on ISSI for the 2014-2018 period. In determining the sample data, this study used a purposive sampling method and obtained a sample of 9 companies. Research data is taken from secondary data, namely performance summary reports and reports on inflation and the US dollar exchange rate. The analytical method used to solve the problem in this research is path analysis using the WarpPLS 7.0 application. From this research, it is found that the lower profitability (ROE) and dividend policy (DPR) has a positive and significant effect on firm value (PBV), inflation has a negative and insignificant effect on firm value (PBV) and the exchange rate (US\$) has a negative effect. and significant to firm value (PBV).
\end{abstract}

Keywords: PBV, ROE, DPR, Inflation and US\$.

\section{Pendahuluan}

Nilai perusahaan ialah harga perusahaan ketika hendak di jual dan di nilai setimpal oleh para calon investor sehingga mereka mau membayarnya. Setiap perusahaan menginginkan nilai perusahaan yang tinggi, dikarenakan nilai perusahaan yang maksimal merupakan tujuan didirikannya suatu perusahaan. Meskipun secara logis, perusahaan didirikan dengan tujuan memperoleh laba yang maksimal, namun menurut para pakar keuangan korporasi, memaksimalkan harta para pemilik saham atau nilai perusahaan ialah tujuan dari perusahaan dalam perspektif manajemen dan bukanlah memaksimalkan laba.

Pemaksimalan nilai perusahaan atau kekayaan pemegang saham bisa memudahkan penakaran kinerja sebuah perusahaan (Nurdin, dkk., 2020). Pada saat harga saham atau nilai perusahaan suatu perusahaan mempunyai trend yang terus naik dalam waktu berkepanjangan, situasi ini bisa menjadi suatu indikator yang menandakan baiknya kinerja perusahaan. Kenaikan pada harga saham atau nilai perusahaan menggambarkan kepercayaan dari pasar pada prospek perusahaan di era mendatang, sehingga dapat berdampak pada pandangan investor terhadap perusahaan. Maka sangat krusial bagi perusahaan untuk selalu berusaha dalam meningkatkan nilai perusahaan (Mardiyanto, 2009).

Nilai perusahaan itu sendiri bisa diperhitungkan dengan PBV, yang merupakan cerminan 
nilai buku saham sebuah perusahaan. PBV (Price to book value) ialah pertimbangan antara harga saham dan nilai buku. PBV membuktikan berapa besar sebuah perusahaan dapat menghasilkan nilai perusahaan dari besar dana yang telah diinvestasikan, hingga rasio PBV yang kian tinggi bisa membuktikan kian berjaya perusahaan dalam menghasilkan nilai untuk pemegang saham (Franita, 2018).

Namun kenyataannya sulit bagi perusahaan untuk terus berupaya dalam mengoptimalkan nilai perusahaan. Dalam upaya mengoptimalkan nilai perusahaan tersebut, perusahaan perlu memperhatikan beberapa faktor. Adapun faktor-faktor yang bisa berdampak pada nilai perusahaan ialah faktor internal dan eksternal. Di mana faktor internal tersebut dapat terdiri dari profitabilitas dan kebijakan dividen, sedangkan faktor eksternal dapat berupa inflasi dan nilai tukar.

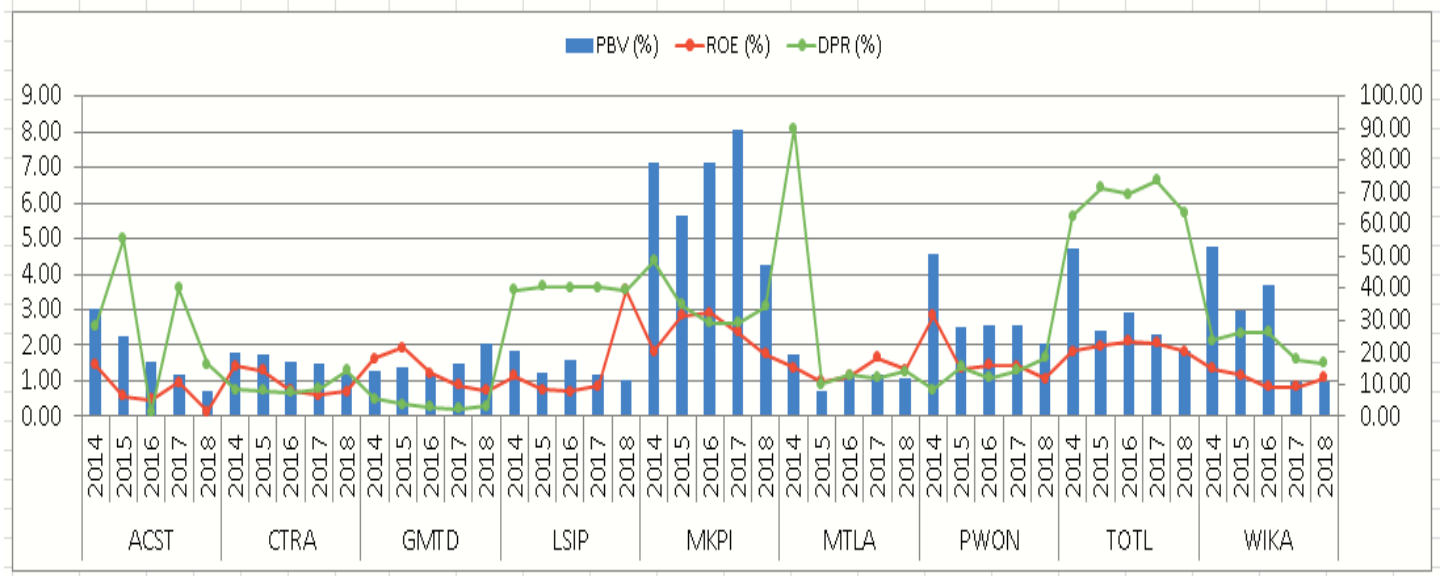

Gambar 1. PBV, ROE dan DPR

Sumber: Laporan kinerja perusahaan, diolah kembali penulis

Dari grafik diatas dapat dilihat, seringkali kenaikan pada profitabilitas (ROE) dan kebijakan dividen (DPR) diikuti oleh kenaikan pada nilai perusahaan (PBV). Namun tidak dengan yang terjadi pada ACST tahun 2017, TOTL tahun 2015 dan WIKA tahun 2018 yang mengalami kenaikan pada DPR dan ROE, tetapi nilai PBV nya mengalami penurunan. Selain itu pada tahun 2018 perusahaan ACST mengalami penurunan pada DPR dan ROE, tetapi PBV nya mengalami kenaikan.

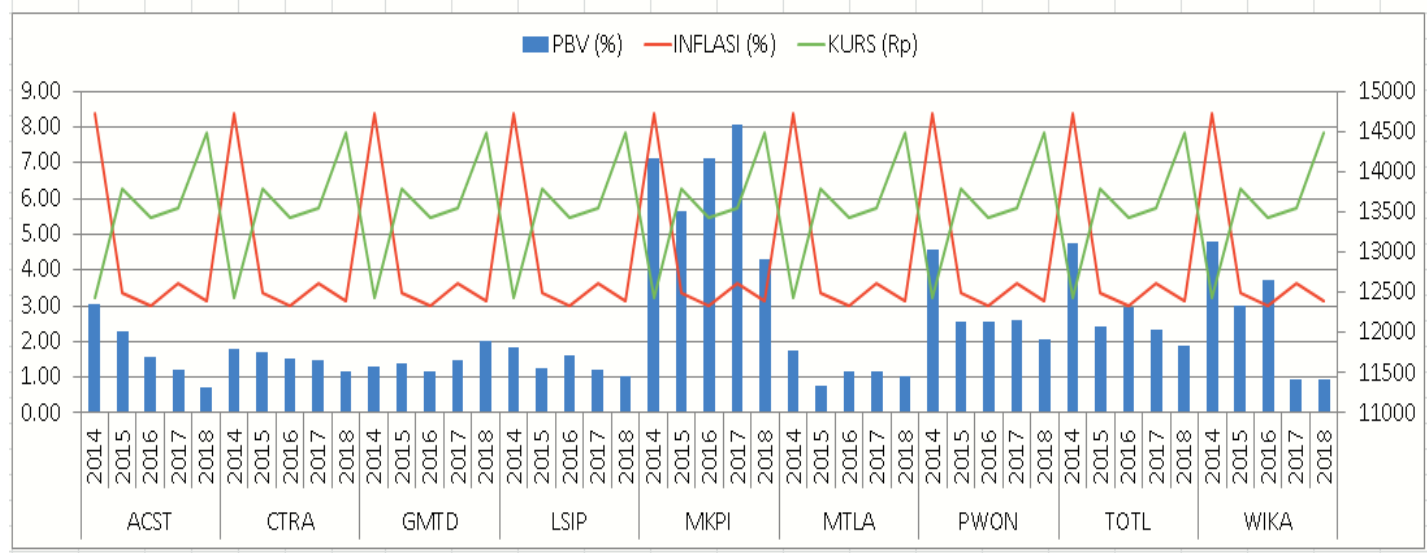

Gambar 2. PBV, Inflasi dan Nilai Tukar (US\$)

Sumber: Laporan kinerja perusabaan, diolah kembali penulis

Pada grafik di atas dapat di lihat kenaikan pada nilai tukar dollar Amerika sering diiringi dengan penurunan nilai perusahaan (PBV). Namun hal itu tidak berlaku bagi perusahaan GMTD tahun 2017-2018, saat nilai tukar dollar Amerika mengalami kenaikan, nilai perusahaan mereka 
juga ikut mengalami kenaikan.

Selain itu dapat di lihat, sebagian besar perusahaan sektor properti, real estate dan konstruksi bangunan memiliki nilai perusahaan yang terus mengalami penurunan setiap tahunnya begitupun dengan tingkat inflasi Indonesia yang cenderung mengalami penurunan setiap tahunnya. Kejadian ini tidak searah dengan pernyataan bahwasanya inflasi memiliki dampak yang negatif bagi nilai perusahaan. Dampak negatif dari inflasi hanya terjadi pada beberapa perusahaan dan pada periode tertentu saja seperti yang dialami perusahaan ACST 2017 LSIP 2017, TOTL 2017 yang mengalami penurunan nilai perusahaan (PBV) dari tahun sebelumnya, kejadian tersebut terjadi saat tingkat inflasi mengalami kenaikan dari 3,02 (2016) menjadi 3,61 (2017).

Beberapa penelitian tentang dampak apa saja yang bisa berdampak pada nilai perusahaan telah dilaksanakan sebelumnya. Penelitian yang dilaksanakan Sucipto dan Sudiyatno (2018) menunjukkan nilai perusahaan terdampak positif serta signifikan oleh profitabilitas. Agustina dan Ardiansari (2015) melaksanakan penelitian yang mengungkapkan nilai perusahaan terdampak tidak signifikan oleh profitabilitas. Selain itu berlandaskan penelitian Martha dkk (2018), nilai perusahaan terdampak tidak signifikan oleh nilai perusahaan.

Penelitian Pasaribu dkk (2019) yang mengungkapkan nilai perusahaan terdampak negatif serta signifikan oleh inflasi dan nilai tukar. Akan tetapi, mengikuti penelitian yang dilaksanakan Fuad dan Wandari (2018) serta Agustina dan Ardiansari (2015), nilai perusahaan terdampak tidak signifikan oleh inflasi dan nilai tukar.

Pada penelitian ini, peneliti menggunakan perusahaan sektor properti, real estate dan konstruksi bangunan yang konsisten tercatat di ISSI selama tahun 2014-2018. Objek penelitian ini dipilih karena ISSI memuat perusahaan sudah sesuai kriteria selaku perusahaan atau emiten yang dapat menerbitkan efek syariah sesuai peraturan OJK.

\section{Kajian Pustaka}

\subsection{Nilai Perusahaan}

Nilai perusahaan ialah harga dari perusahaan ketika hendak dipasarkan dan dinilai setimpal oleh para calon investor sehingga mereka mau membayarnya. Bagi perusahaan yang memasarkan sahamnya pada publik, indikator nilai perusahaannya ialah harga saham yang dipasarkan di bursa efek. Kian tinggi harga saham, maka nilai perusahaan tersebut akan meningkat juga. (M. Fuad dkk, 2000).

Nilai perusahaan bisa tergambar lewat harga saham. PBV (Price to book value) ialah salah satu indikator dalam menilai perusahaan. PBV Memvisualkan berapa banyak pasar memandang nilai buku saham sebuah perusahaan.

\subsection{Profitabilitas}

Menurut Hery (2015), rentabilitas (profitabilitas) merupakan keahlian suatu usaha untuk memperoleh sejumlah keuntungan yang berasal dari aktivitas normal bisnis perusahaan selama periode tertentu. Profitabilitas bisa di jumlah menggunakan ROE (Return On Equity) (Setyowati et al., 2019). Keuntungan akan ekuitas (Return on Equity) ialah rasio yang menggambarkan sejumlah banyak pengaruh ekuitas dapat menghasilkan keuntungan bersih. Kian tinggi ROE dapat diartikan kian tingginya jumlah keuntungan bersih yang didapatkan dari setiap rupiah modal yang tersedia. ROE yang tinggi bisa menaikkan harga saham serta bisa menarik hasrat para investor buat menanamkan dananya ke dalam perusahaan sehingga terdapat hubungan positif antara profitabilitas dan harga saham, di mana kenaikan nilai perusahaan dapat disebabkan karena kenaikan harga saham perusahaan tersebut. Pernyataan tercantum searah dengan teori Irrelevant yang dipelopori oleh MM, yang melaporkan nilai suatu perusahaan dapat dipasarkan oleh keuntungan yang dihasilkan suatu perusahaan. Berlandaskan penelitian yang dilaksanakan oleh 
Martha dkk. (2018) dan Sucipto dan Sudiyatno (2018) didapatkan hasil nilai perusahaan terdampak positif serta signifikan oleh profitabilitas.

\subsection{Kebijakan Dividen}

Menurut Sawir (2004), kebijakan dividen melibatkan apakah keuntungan bakal dialokasikan menjadi dividen ataukah menahannya buat diinvestasikan lagi pada perusahaan. Kebijakan dividen dan keputusan pendanaan perusahaan merupakan satu bagian yang menyatu. Dimana semakin besar jumlah keuntungan ditahan, maka semakin kecil besar dividen dibagikan. Kebijakan dividen bisa ditakar oleh DPR. DPR (Dividend Payout Ratio) ialah perbandingan antara dividen yang didistribusikan dan keuntungan bersih setiap saham.

Berlandaskan teori Bird-In The Hand, rasio pembagian dividen yang besar dapat mengoptimalkan nilai perusahaan, karena adanya anggapan investor bahwasanya dividen aktual memiliki risiko yang lebih rendah dibandingkan dengan capital gain yang mungkin akan dicapai. Teori Signaling Hypothesis juga melaporkan hal yang sama yaitu kenaikan dividen kerap kali diiringi dengan peningkatan harga saham dan ujungnya bakal meningkatkan nilai perusahaan. Dari penelitian yang dilaksanakan Sucipto dan Sudiyatno (2018) serta Odinya dan Barasa (2018), nilai perusahaan terdampak positif serta signifikan oleh kebijakan dividen.

\subsection{Inflasi}

Inflasi ialah naiknya harga barang atau jasa pada umumnya dan berlangsung secara berkepanjangan, alasannya kerana ketersediaan uang beredar kian banyak daripada kesiapan barang atau jasa (Firdaus \& Ariyanti, 2011). Pada saat inflasi terjadi, daya beli masyrakat terhadap mata uang akan turun, hingga dalam memenuhi kebutuhan untuk konsumsi barang yang serupa diperlukan sejumlah uang yang lebih banyak dari biasanya. (Anisa \& Tripuspitorini, 2019).

Rahardja dan Manurung (2004) melaporkan inflasi dapat berdampak buruk baik bagi masyarakat, perusahaan maupun bagi perekonomian secara keseluruhan. Salah satu dampaknya adalah berkurangnya investasi karena masyarakat akan mengalami kesulitan dalam memenuhi kebutuhannya dan perusahaan akan kesulitan dalam produksi, karena harga bahan baku produksi meningkat (Tripuspitorini \& Setiawan, 2020). Semua situasi itu bakal berakhir pada penurunan keuntungan yang diperoleh perusahaan serta penurunan nilai perusahaan. Pasaribu dkk. (2019) serta Fuad dan Wandari (2018) dalam penelitiannya mengungkapkan nilai perusahaan terdampak negatif dan signifikan oleh inflasi.

\subsection{Nilai Tukar}

Menurut Hasibuan dan Malayu (2001) nilai tukar adalah banyaknya jasa atau barang yang bisa didapatkan dengan satuan atau pecahan uang. Nilai tukar atau sering disebut kurs ialah perbandingan harga mata uang satu negara dengan negara lainnya (Tripuspitorini \& Setiawan, 2020).

Kenaikan pada nilai tukar dapat berdampak buruk bagi perusahaan. Bagi perusahaan yang berorientasi pada impor, kenaikan Dollar AS (US\$) bisa mengakibatkan naiknya biaya untuk impor bahan pokok produksi, di mana hal itu bisa menyebabkan penurunan dividen yang bakal diberikan pada para pemegang saham dan ujungnya bisa menurunkan nilai perusahaan (Harianto \& Sudomo, 2001). Pasaribu dkk. (2019) dalam penelitiannya mengungkapkan nilai perusahaan terdampak negatif serta signifikan oleh nilai tukar.

\section{Metode Penelitian}

\subsection{Metode Penelitian}

Metode yang dipakai pada penelitian ini ialah metode kuantitatif deskriptif, yaitu jenis penelitian atas tujuan mendeskripsikan fakta atau fenomena secara detail secara sistematis, faktual dan akurat (Yusuf, 2014).

\subsection{Jenis dan Sumber Data}

Data penelitian ini berasal dari data sekunder dari laporan ringkasan kinerja perusahaan 
2014-2018 yang bisa di unduh di www.idx.co.id, serta laporan Bank Indonesia (BI) mengenai inflasi dan kurs dollar Amerika terhadap rupiah periode 2014-2018 yang dipublikasikan di www.bi.go.id.

\subsection{Populasi dan Sampel Penelitan}

Populasi penelitian ini ialah perusahaan sektor properti real estate dan konstruksi bangunan yang konsisten tercatat di ISSI selama 2014-2018. Dalam menentukan sampel digunakan metode purposive sampling. Adapun beberapa syarat yang perlu dipenuhi ialah:

1. Perusahaan sektor properti real estate dan konstruksi bangunan yang konsisten tercatat di ISSI selama 2014-2018.

2. Memiliki rasio nilai Return On Equity yang positif selama periode 2014-2018.

3. Selama periode 2014-2018, perusahaan membagikan dividennya secara berkala.

Berlandaskan kriteria sampel diatas, maka didapatkan 9 perusahaan yang memenuhi kriteria tersebut. Adapun perusahaan yang dimaksud adalah sebagai berikut:

Tabel III.1 Daftar Perusahaan

\begin{tabular}{|c|c|c|}
\hline No. & Kode Perusahaan & Nama Perusahaan \\
\hline 1. & ACST & Acset Indonesia \\
\hline 2. & CTRA & Ciputra Development \\
\hline 3. & GMTD & Gowa Makassar Tourism Development \\
\hline 4. & LSIP & PP London Sumatra Indonesia \\
\hline 5. & MKPI & Metropolitan Kentjana \\
\hline 6. & MTLA & Metropolitan Land \\
\hline 7. & PWON & Pakuwon Jati \\
\hline 8. & TOTL & Total Bangun Persada \\
\hline 9. & WIKA & Wijaya Karya \\
\hline
\end{tabular}

Sumber: Bursa Efek Indonesia, data diolah kembali

\section{4. $\quad$ Metode Analisis}

Metode analisis yang dimanfaatkan untuk menyelesaikan masalah pada penelitian ini ialah analisis jalur. Analisis data dalam penelitian ini memanfaatkan program (software) WarpPLS versi 7.0. PLS dapat digunakan untuk mengkonfirmasi teori atau uji hipotesis. Selain itu, analisis dengan WarpPLS tidak mengharuskan asumsi distribusi data, yaitu data tidak diharuskan terdistribusi normal. Situasi tersebut telah terlaksana saat proses pengetesan hipotesis yang melibatkan pemakaian resampling.

Analisis jalur, dimanfaatkan untuk menelaah hubungan sebab akibat antara variabel eksogen (exogenous) dengan variabel endogen (endogenous). Di mana model analisis jalur perlu dilandasi teori yang kuat, sehingga analisis jalur yang dihasilkan dapat menjelaskan fenomena yang dipelajari. Mengenai tindakan-tindakan untuk melaksanakan analisis jalur ialah sebagai berikut.

1. Model dirancang berlandaskan pada teori.

Melakukan eksplorasi ilmiah melalui telaah pustaka mengenai variabel-variabel yang digunakan serta hubungan kausalitasnya guna mendapatkan justifikasi atas model teoristis yang dikembangkan.

2. Pengembangan diagram jalur atau path diagram

Model yang telah dirancang berdasarkan teori kemudian digambarkan dalam bentuk path diagram untuk memudahkan dalam mengamati hubungan kausalitas yang di uji. 


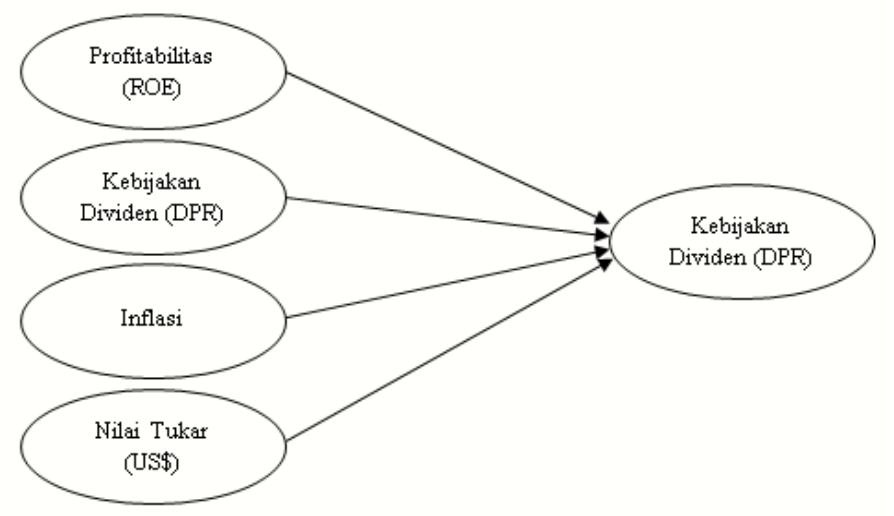

Gambar III.11Diagram Jalur

Sumber: Data diolab penulis

3. Konversi diagram jalur ke dalam persamaan

$\mathrm{PBV}=\beta_{1} \mathrm{ROE}+\beta_{2} \mathrm{DPR}+\beta_{3}$ Inflasi $+\beta_{4}$ Nilaitukar $+\varepsilon$

Keterangan:

$\begin{array}{lll}\beta_{1}, \beta_{2}, \beta_{3}, \beta_{4} & : & \text { Koefisien yang diestimasi } \\ \text { PBV } & : & \text { Price Book Value } \\ \text { ROE } & : & \text { Return on Equity } \\ \text { DPR } & : & \text { Dividend Payout Ratio } \\ \varepsilon & : & \text { Standar error atau residual }\end{array}$

4. Goodness of Fit Model

Goodness fit sendiri merupakan indeks dan patokan kebagusan ikatan antar variabel laten terkait juga dengan dugaan-dugaannya. Intinya, bila goodness of fit terpenuhi, model bisa dibilang benar, sehingga bisa dipakai dalam menerangkan kaitan-kaitan antar variabel yang ada dalam model.

Solimun dkk. (2017) mengungkapkan bahwa kriteria goodness fit berkarakter rule of thumb, jadi senormalnya tidak berfungsi secara baku dan mutlak. Indikator model fit jadi kurang krusial, apabila tujuan analisis cuman untuk mengevaluasi hipotesis ikatan antar variabel laten (biasanya disebut sebagai strictly confirmatory). Namun, bila tujuan analisis untuk memastikan model paling baik dari banyak model yang tidak sama (competing models) maka indeks fit sangat penting.

5. Uji hipotesis

- Hipotesis 1

$\mathrm{H}_{0}$ : Profitabilitas (ROE) tidak berdampak positif serta signifikan pada nilai Perusahaan (PBV).

$\mathrm{H}_{\mathrm{a}}$ : Profitabilitas (ROE) berdampak positif serta signifikan pada nilai perusahaan (PBV).

- Hipotesis 2

$\mathrm{H}_{0}$ : Kebijakan dividen (DPR) tidak berdampak positif serta signifikan pada nilai perusahaan (PBV).

$\mathrm{H}_{\mathrm{a}}$ : Kebijakan dividen (DPR) berdampak positif serta signifikan pada nilai perusahaan (PBV).

- Hipotesis 3

$\mathrm{H}_{0}$ : Inflasi tidak berdampak negatif serta signifikan pada nilai perusahaan (PBV).

$\mathrm{H}_{\mathrm{a}}$ : Inflasi berdampak negatif serta signifikan pada nilai perusahaan (PBV).

- Hipotesis 4 
$\mathrm{H}_{0}$ : Nilai Tukar tidak berdampak negatif serta signifikan pada nilai perusahaan (PBV).

$\mathrm{H}_{\mathrm{a}}$ : Nilai Tukar berdampak negatif serta signifikan pada nilai perusahaan (PBV).

Dari keempat hipotesis yang telah disebutkan di atas, dasar pengambilan keputusannya adalah:

p-value $\geq 0,05$, hingga $\mathrm{H}_{0}$ diterima dan $\mathrm{H}_{\mathrm{a}}$ ditolak

p-value $\leq 0,05$, hingga $\mathrm{H}_{\mathrm{a}}$ diterima dan $\mathrm{H}_{0}$ ditolak

6. Interpretasi Hasil Analisis

Melakukan interprestasi hasil analisis dengan menentukan jalur-jalur pengaruh signifikan dan mengidentikasi jalur yang pengaruhnya lebih kuat dengan membandingkan besar nilai dari koefisien jalur.

\section{Hasil dan Pembahasan}

\subsection{Hasil}

1. Analisis Jalur

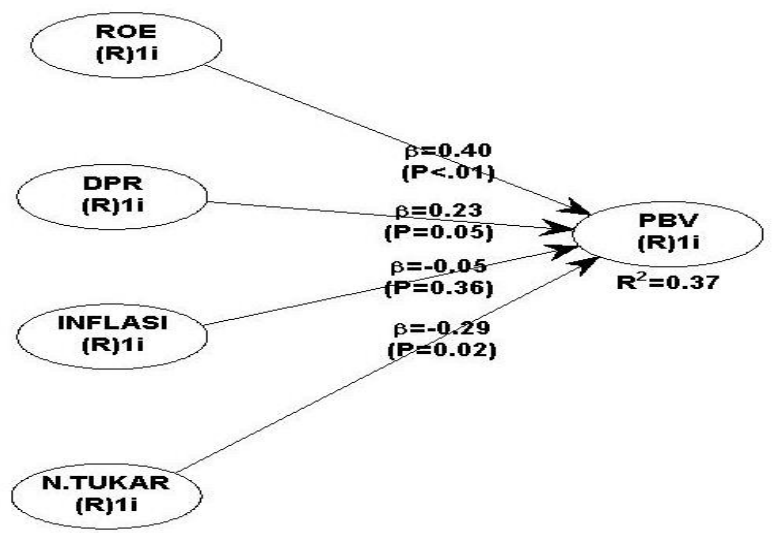

\section{Gambar IV.12Hasil Analisis Jalur Secara Parsial}

Sumber: Output Warppls 7.0

Berlandaskan hasil pengujian analisis jalur diatas, dapat dilihat pengaruh antara ROE (Profitabilitas), DPR (kebijakan dividen), inflasi dan nilai tukar (US\$) selaku parsial pada nilai perusahaan (PBV). Diperoleh hasil berikut ini:

a. Dampak profitabilitas (ROE) pada nilai perusahaan (PBV) signifikan, nilai koefisien jalur 0,40 dan $\mathrm{p}$-value $<0,01$.

b. Dampak DPR (kebijakan dividen) pada nilai perusahaan (PBV) signifikan, nilai koefisien jalur 0,23 dan p-value 0,05 .

c. Dampak inflasi pada nilai perusahaan (PBV) tidak signifikan, nilai koefisien jalur -0,05 dan p-value 0,36 .

d. Dampak nilai tukar (US\$) pada nilai perusahaan (PBV) signifikan, nilai koefisien jalur -0,29 dan p-value 0,02.

2. Hasil Persamaan Penelitian

$$
\mathrm{PBV}=0,40 \mathrm{ROE}+0,23 \mathrm{DPR}-0,05 \text { Inflasi }-0,29 \mathrm{Nilaitukar}+\varepsilon
$$

Adapun penjelasan hasil persamaan diatas adalah sebagai berikut:

a. Andaikan profitabilitas (ROE) naik sebanyak 1 besaran, hingga nilai perusahaan (PBV) bisa naik sebanyak 0,40 dengan anggapan variabel lainnya tetap atau konstan.

b. Andaikan kebijakan dividen (DPR) naik sebanyak 1 besaran, hingga nilai perusahaan (PBV) bisa naik sebanyak 0,23 dengan anggapan variabel lainnya tetap atau konstan. 
c. Andaikan kebijakan dividen (DPR) naik sebanyak 1 besaran, hingga nilai perusahaan (PBV) bisa turun sebanyak 0,05 dengan anggapan variabel lainnya tetap atau konstan.

d. Andaikan kebijakan dividen (DPR) naik sebanyak 1 besaran, hingga nilai perusahaan (PBV) bisa turun sebanyak 0,29 dengan anggapan variabel lainnya tetap atau konstan.

7. Hasil Uji Goodness of Fit Model

Berlandaskan hasil pengujian yang sudah dilakukan, bisa diamati APC memiliki nilai sebanyak 0,245 dan p-value dengan nilai 0,019; ARS memiliki nilai sebanyak 0,373 dan p-value dengan nilai sebanyak 0.001; AARS memiliki nilai sebanyak 0,310 serta $p$-value bernilai 0,006 . Di antara APC, ARS dan ARRS, ketiganya diterima sebab nilai $\mathrm{p}$-value $<0,05$, berarti model mempunyai nilai model fit yang baik. AVIF dan AFVIF diterima karena nilainya $\leq 5$ dan ideal $\leq 3,3$, nilai AVIF sebesar 1,178 dan AFVIF sebesar 1.358. Bila dilihat dari hasil nilai AVIF dan AFVIF, model tidak mengalami gejala multikolonieritas. GoF termasuk kategori besar, karena nilainya $0,610 \geq 0,36$, berarti model fit sangat baik. Nilai SPR sebesar 0,750 diterima karena $\geq 0,7$. RSCR dan SSR diterima, dengan nilai RSCR sebanyak 0,974 $\geq 0,9$ dan nilai SSR sebanyak $1,000 \geq 0,7$. NLBCR memiliki nilai $1,000 \geq 0,7$, maka diterima. Dilihat dari nilai SPR, RSCR, SSR dan NLBCDR, model tidak memiliki masalah kausalitas.

Pada uji Goodnness of Fit Model ini ada 3 indeks pengujian, ialah APC, ARS dan AVIF. Dimana APC dan ARS bisa diterima dengan ketentuan p-value nilainya kurang dari 0,05 dan AVIF nilainya lebih dari 5 . Sehingga secara keseluruhan model penelitian ini telah memenuhi kriteria model fit dan dapat diterima (Raina et al., 2020).

8. Hasil Pengujian Hipotesis

a. Hipotesis 1

Variabel ROE (profitabilitas) memiliki nilai koefisien jalur sebanyak 0,40 dan p-value $<0,01$, di mana $\mathrm{p}$-value terkait nilainya kurang dari $\alpha=0,05$, hingga bisa dinyatakan profitabilitas (ROE) berdampak positif serta signifikan pada nilai perusahaan (PBV) atau $\mathrm{H}_{\mathrm{a}}$ diterima dan menolak $\mathrm{H}_{0}$.

b. Hipotesis 2

Variabel DPR (kebijakan dividen) memiliki nilai koefisien jalur sebanyak 0,23 dan $\mathrm{p}$ value 0,05 , di mana nilai $\mathrm{p}$-value terkait sama dengan dari $\alpha=0,05$, hingga dapat dinyatakan kebijakan dividen (DPR) berdampak positif serta signifikan pada nilai perusahaan (PBV) atau $\mathrm{H}_{\mathrm{a}}$ diterima dan menolak $\mathrm{H}_{0}$.

c. Hipotesis 3

Variabel inflasi memiliki nilai koefisien jalur sebanyak $-0,05$ dan p-value $<0,36$, di mana p-value terkait memiliki nilai lebih dari $\alpha=0,05$, hingga bisa diungkapkan inflasi berdampak negatif dan signifikan pada nilai perusahaan (PBV) atau $\mathrm{H}_{0}$ diterima dan menolak $\mathrm{H}_{a}$.

d. Hipotesis 4

Variabel nilai tukar (US\$) mempunyai nilai koefisien jalur sebanyak -0,29 dan p-value 0,02 , di mana nilai p-value terkait kurang dari $\alpha=0,05$, hingga bisa diungkapkan

nilai tukar (US\$) berdampak negatif dan tidak signifikan pada nilai perusahaan (PBV) atau $\mathrm{H}_{\mathrm{a}}$ diterima dan menolak $\mathrm{H}_{0}$.

\subsection{Pembahasan}

1. Dampak Profitabilitas pada Nilai Perusahaan

Berlandaskan analisis yang dilaksanakan didapatkan hasil profitabilitas berdampak positif serta signifikan pada nilai perusahaan. Hasil penelitian ini sesuai dengan penelitian yang dilaksanakan oleh Martha dkk. (2018) serta Sucipto dan Sudiyatno (2018) yang melaporkan nilai perusahaan terdampak positif dan signifikan oleh profitabilitas. Menurut Hery (2015), profitabilitas yang tinggi bisa menarik minat investor untuk menanamkan modal di perusahaan dan bakal menaikkan harga saham yang akhirnya bisa meninggikan nilai 
perusahaan, situasi ini searah dengan teori irrelevant yang menjelaskan sesungguhnya nilai perusahaan ditentukan oleh keuntungan atau arus kas yang dihasilkan oleh suatu perusahaan. Tapi tidak sama dengan penelitian yang dilaksanakan oleh Putra dan Sulasmiyati (2019), yang melaporkan nilai perusahaan terdampak tidak dan signifikan oleh profitabilitas.

2. Dampak Kebijakan Dividen pada Nilai Perusahaan

Berlandaskan analisis yang dilakukan diperoleh hasil kebijakan dividen berdampak positif serta signifikan pada nilai perusahaan. Penelitian ini searah dengan hasil penelitian yang sebelumnya dilaksanakan Sucipto dan Sudiyatno (2018) serta Odinya dan Barasa (2018) yang melaporkan nilai perusahaan terdampak positif dan signifikan oleh kebijakan dividen. Berlandaskan teori Bird-In The Hand, rasio pembagian dividen yang tinggi bisa mengoptimalkan nilai perusahaan. Selain itu teori Signaling Hypothesis juga melaporkan kenaikan dividen kerap kali diiringi bersama kenaikan harga saham yang ujungnya bakal menaikkan nilai perusahaan. Tapi tidak sama dengan penelitian yang dilaksanakan oleh Martha dkk. (2018) yang melaporkan sesungguhnya nilai perusahaan terdampak tidak signifikan oleh kebijakan dividen.

3. Dampak Inflasi pada Nilai Perusahaan

Berlandaskan analisis yang dilaksanakan didapatkan hasil inflasi berdampak negatif serta tidak signifikan pada nilai perusahaan. Negatifnya inflasi pada penelitian ini searah dengan pendapat Rahardja dan Manurung (2004), yang melaporkan bahwa salah satu dampak dari inflasi adalah berkurangnya investasi yang bisa menurunkan nilai perusahaan. Menurut Putra dan Sulasmiyati (2019), inflasi berpengaruh tidak signifikan sebab pada tahun 20142018, tingkat inflasi tergolong inflasi rendah dengan nilai di bawah 10\%, sehingga investor masih yakin untuk tetap menanamkan modalnya pada perusahaan sektor properti real estate dan konstruksi bangunan.

Hasil ini searah dengan hasil penelitian sebelumnya yang dilaksanakan Fuad dan Wandari (2018), yang melaporkan nilai perusahaan terdampak negatif dan tidak signifikan oleh inflasi. Tapi hasil ini tidak sama dengan Pasaribu dkk. (2018) yang melaporkan bahwa nilai perusahaan terdampak signifikan oleh inflasi.

4. Dampak Nilai Tukar pada Nilai Perusahaan

Berlandaskan analisis yang dilakukan didapatkan hasil nilai tukar berdampak negatif dan tidak signifikan pada nilai perusahaan. Menuruti Harianto dan Sudomo (2001) yangmelaporkan menguatnya mata uang asing atau melemahnya nilai rupiah bisa menaikkan biaya untuk impor bahan pokok produksi, yang akan berpengaruh pada penurunan perolehan laba dan mengakibatkan penurunan dividen yang diberikan perusahaan kepada pemegang saham, yang akhirnya bisa menurunkan nilai perusahaan. Penelitian ini menggunakan periode tahun 2014-2018, di mana pada periode ini kurs dollar Amerika terus mengalami kenaikan setiap tahunnya yang menyebabkan melemahnya nilai rupiah. Searah dengan penelitian yang dilaksanakan oleh Pasaribu dkk. (2019), yang mengungkapkan nilai perusahaan terdampak negatif dan signifikan oleh nilai tukar. Menurut Pasaribu dkk. (2019), tingginya nilai dollar Amerika atau melemahnya rupiah akan meningkatkan beban pembelian untuk material bangunan yang di impor. Situasi ini bisa berdampak pada naiknya beban untuk produksi dan turunnya profitabilitas perusahaan, sehingga berimbas pada penurunan nilai perusahaan. Tapi tidak sama dengan penelitian Fuad dan Wandari (2018), yang melaporkan nilai perusahaan terdampak negatif dan tidak signifikan oleh nilai tukar.

\section{Penutup}

\subsection{Kesimpulan}

Berlandaskan pengujian yang sudah dilaksanakan dalam penelitian ini hingga bisa 
disimpulkan bahwasanya:

1. Profitabilitas memiliki dampak positif serta signifikan pada nilai perusahaan. Hingga dapat dibuktikan sesungguhnya semakin tinggi keuntungan yang diciptakan perusahaan, bisa menaikkan nilai perusahaan.

2. Kebijakan dividen memiliki dampak positif serta signifikan pada nilai perusahaan. Sehingga dapat dibuktikan bahwa semakin tinggi dividen yang dibagikan, bisa meningkatkan nilai perusahaan.

3. Inflasi memiliki dampak negatif serta tidak signifikan pada nilai perusahaan. Sehingga dapat dibuktikan sesungguhnya semakin tinggi tingkat inflasi, bisa menurunkan nilai perusahaan meskipun tidak signifikan. Dengan kata lain, kenaikan tingkat inflasi tidak selalu diiringi bersama penurunan nilai perusahaan.

4. Nilai tukar memiliki dampak negatif serta signifikan pada nilai perusahaan,. Sehingga dapat dibuktikan sesungguhnya semakin tinggi nilai tukar dollar Amerika atau melemahnya nilai rupiah, bisa menurunkan nilai perusahaan.

\subsection{Saran}

Berlandaskan hasil analisis, bisa dibagikan beberapa saran dengan angan-angan penelitian sejenis sesudah ini bisa mempunyai hasil yang lebih baik. Adapun saran-saran yang bisa diberikan, yaitu:

1. Setiap investor menginginkan perusahaan yang dipilihnya untuk berinvestasi memiliki kinerja dan prospek yang baik, sehingga sebelum berinvestasi sebaiknya investor memperhatikan nilai tukar dollar Amerika serta pertimbangkan riwayat profitabilitas dan kebijakan dividen perusahaan tersebut, dikarenakan variabel-variabel terkati bisa berimbas pada nilai perusahaan.

2. Untuk perusahaan go public, hasil penelitian ini bisa menjadi bahan evaluasi dalam meningkatkan nilai perusahaan. Perusahaan perlu memperhatikan faktor eksternal seperti nilai tukar dollar Amerika dalam mengambil keputusan yang berkaitan dalam meningkatkan nilai perusahaan, karena nilai tukar dollar Amerika memberikan dampak negatif pada nilai perusahaan. Selain itu, perusahaan perlu memperhatikan faktor internal seperti profitabilitas yang dicapai dan kebijakan dividen yang ditetapkan, karena peningkatan profitabilitas dan kebijakan dividen akan meningkatkan nilai perusahaan.

3. Untuk calon peneliti agar menggunakan sampel yang lebih luas, menggunakan variabel lain yang relevan dan potensial serta periode yang tidak sama untuk mendapatkan hasil temuan yang dapat dibandingkan dengan temuan-temuan sebelumnya.

\section{Daftar Pustaka}

Agustina, C., \& Ardiansari, A. (2015). Pengaruh Faktor Ekonomi Makro Dan Kinerja Keuangan Terhadap Nilai Perusahaan. Management Analysis Journal, 4(1), 1021.https://doi.org/10.15294/maj.v4i1.7203

Anisa, L. S., \& Tripuspitorini, F. A. (2019). Analisis Pengaruh Dana Pihak Ketiga, Non Performing Finance Murabahah, Dan Inflasi Terhadap Pembiayaan Murabahah Pada Bank Umum Syariah Di Indonesia. Jurnal Maps (Manajemen Perbankan Syariah), 3(1), 52-64. https://doi.org/10.32483/maps.v3i1.30

Firdaus, R., \& Ariyanti, M. (2011). Pengantar Teori Moneter Serta Aplikasinya pada Sistem Ekonomi Konvensional \& Syariah. Alfabeta.

Franita, R. (2018). Mekanisme Good Corporate Governance dan Nilai Perusahaan Studi untuk Perusabaan Telekomunikasi. Lembaga Penelitian dan Penulisan Ilmiah Aqli.

Fuad, M., H., C., Nurlela, Sugiarto, \& Y.E.F, P. (2000). Pengantar Bisnis. Gramedia Pustaka Utama. 
Fuad, Muhammad, \& Wandari, A. (2018). Pengaruh Struktur Modal dan Faktor Eksternal terhadap Nilai Perusahaan (Studi pada PT. Bank Central Asia, Tbk). Jurnal Manajemen dan Keuangan, 7(1), 32-46. https://doi.org/10.33059/jmk.v7i1.755

Harianto, \& Sudomo. (2001). Merger dan Akuisisi. Jurnal Manajemen.

Hasibuan S.P, \& Malayu, H. (2001). Dasar-Dasar Perbankan. Bumi Aksara.

Hery. (2015). Analisis Kinerja Manajemen. Grasindo.

Martha, L., Sogiroh, N. U., Magdalena, M., Susanti, F., \& Syafitri, Y. (2018). Profitabilitas Dan

Kebijakan Dividen Terhadap Nilai Perusahaan. Jumal Benefita, 3(2), 227. https://doi.org/10.22216/jbe.v3i2.3493

Nurdin, A. A., Mai, M. U., \& Setiawan, S. Pola Kinerja Perusahaan Sesudah Merger dan Akuisisi serta Analisis Terhadap Faktor-Faktor yang Mempengaruhinya. Jurnal Riset Akuntansi dan Keuangan, 8(2), 431-446.

Odinya, A. F., \& Barasa, J. (2018). The Effect of Dividend Policy on the Value of Firms Listed at the Nairobi Securities Exchange. African Development Finance Journal (ADFJ), 2(1)., 2(1), 134 145. https://doi.org/10.1109/robot.1994.350900

Pasaribu, U. R., Nuryartono, N., \& Andati, T. (2019). Pengaruh Faktor Internal Dan Eksternal Perusahaan Terhadap Nilai Perusahaan. Jurnal Aplikasi Bisnis dan Manajemen, 5(3), 441-454. https://doi.org/10.17358/jabm.5.3.441

Putra, R. H., \& Sulasmiyati, S. (2019). Pengaruh Faktor Eksternal dan Internal Terhadap Nilai Perusahaan (Studi pada Perusahaan Subsektor Properti dan Real Estate yang Terdaftar di Bursa Efek Indonesia Periode 2014-2017). Jurnal Administrasi Bisnis (JAB), 72(2), 21-29.

Rahardja, P., \& Manurung, M. (2004). Teori Ekonomi Makro Suatu Pengantar. Fakultas Ekonomi Indonesia.

Raina, N. G., Mai, M. U., \& Setiawan. (2020). Pengaruh Corporate Sosial Responsibility Terhadap Kinerja Perusahaan pada Perusahaan Manufaktur Syariah. Jurnal Ekonomi Bisnis, 19(1), 6978. https://doi.org/10.17509/jrak.v8i1.20065

Sawir, A. (2004). Kebijakan Pendanaan dan Rekontrukturisasi Perusabaan. Gramedia Pustaka Utama.

Setyowati, D. H., Sartika, A., \& Setiawan, S. (2019). Faktor-Faktor yang Mempengaruhi Pangsa Pasar Industri Keuangan Syariah Non-Bank. Jurnal Iqtisaduna, 5(2), 169-186.

Sucipto, E., \& Sudiyatno, B. (2018). Profitabilitas, Kebijakan Dividen, Dan Kebijakan Hutang Terhadap Nilai Perusahaan Pada Perusahaan Manufaktur Yang Listed Di Bursa Efek Indonesia. Dinamika Akuntansi, Keuangan dan Perbankan Definisi, 7(2), 163-172.

Tripuspitorini, F. A., \& Setiawan. (2020). Pengaruh Variabel Makroekonomi Terhadap Dana Pihak Ketiga Bank Umum Syariah Di Indonesia. Jurnal Muara Ilmu Ekonomi dan Bisnis, 4(1), 164. https://doi.org/10.24912/jmieb.v4i1.7299

Yusuf, M. (2014). Metode Penelitian Kuantitatif, Kualitatif, dan Penelitian Gabungan. Kencana. 